Article

\title{
Derrida Contra Agamben: Sovereignty, Biopower, History
}

\author{
Amy Swiffen \\ Department of Sociology and Anthropology, Concordia University, 1455 de Maisonnueve Blvd. W., \\ Montreal, H3G 1M8, Canada; E-Mail: amy.swiffen@concordia.ca
}

Received: 30 September 2012; in revised form: 15 November 2012 / Accepted: 19 November 2012 /

Published: 5 December 2012

\begin{abstract}
This essay is concerned with criticisms of Giorgio Agamben's biopolitical theory of sovereignty that are developed by Jacques Derrida in his final seminar titled The Beast and the Sovereign (2009). The implicit interlocutor for much of the seminar is theories of biopolitics. However, when these theories are addressed explicitly, it is through the work of Agamben. The article proceeds first with a brief account of the main issues that preoccupy Derrida in the seminar. In general, these relate to conceptualizing sovereignty and its relationship to the division between human and animal. The second section introduces the criticisms of Agamben, which are articulated initially in terms of the latter's tendency to declare the origin of ideas and concepts. The third section outlines some central aspects of Agamben's theory that are pertinent for evaluating Derrida's criticisms. The fourth section turns to the conceptual and textual basis for the criticisms, which involve a way of thinking history and an interpretation of Aristotle. The final section of the paper extrapolates the implications of Derrida's criticisms for thinking sovereignty and its future.
\end{abstract}

Keywords: Jacques Derrida; Giorgio Agamben; sovereignty; biopolitics and biopower; law

\section{Introduction}

This essay is concerned with the criticisms of Giorgio Agamben's biopolitical theory of sovereignty that are developed by Jacques Derrida in his final seminar titled The Beast and the Sovereign [1]. The implicit interlocutor for much of the seminar is theories of biopolitics. However, when these theories are addressed explicitly, it is through the work of Agamben, and specifically the book Homo Sacer: Sovereign Power and Bare Life [2]. The discussion in this paper proceeds first with a brief account of the main issues that preoccupy Derrida in the seminar. In general, these issues relate to modes of 
conceptualizing sovereignty and their relationship to the division between human and animal. The second section of the paper introduces Derrida's criticisms of Agamben, which are articulated in terms of the latter's tendency to declare the origin of ideas and concepts. The third section outlines some central aspects of Agamben's theory that are pertinent for evaluating Derrida's criticisms. The fourth section turns to the conceptual and textual basis for the criticisms, which involve a way of thinking history and an interpretation of Aristotle. The final section demonstrates how Derrida does not just complicate the distinctions that Agamben makes in his theory, but uses the notion of animality to propose a very different understanding of sovereignty. The paper concludes by extrapolating the implications of Derrida's position for thinking sovereignty and its future.

\section{Responsible Sovereigns}

The Beast and the Sovereign contains a series of readings of texts in political theory and literature that address the concept of sovereignty, including texts by Aristotle, La Fontaine, Machiavelli, Hobbes, Rousseau and Schmitt. One of the central themes is how sovereigns and beasts form a figural pair, consistently paralleling and overlapping each other. In each case, Derrida draws attention to the array of images, metaphors and analogies that link sovereignty to the figure of the beast. He shows repeatedly how the figures are represented as bearing a strange resemblance, in particular in being "outside-the-law" ([1], p. 17). ${ }^{1}$ At the same time, there is a plethora of forms of this resemblance, which corresponds to another important theme of the seminar: there is no single threshold or essence of sovereignty. Derrida states in various ways that there exists, "Not the beast and the sovereign," and that there is, "No one sovereignty ([1], p. 101)." Each session in the seminar, therefore, tries to demonstrate both that sovereignty is tied to the figure of the beast, and, at the same time, that there is a perpetual openness to the concept of sovereignty. This openness is in turn related to the 'undecidability' of the division of animal/human.

Derrida's reading of Thomas Hobbes' Leviathan is exemplary in this regard. It focuses on how Hobbes tried to 'anthropologize' and 'humanize' the foundation of sovereignty with the concept of the social contract ([1], p. 53). It was important for Hobbes to establish that the Leviathan was not a phenomenon of nature, but a uniquely human creation. The sovereign, he insisted, is an 'Artificial Man' with an 'Artificial Soul' (Hobbes quoted in [1], pp. 27-28). This idea is based on excluding the possibility that a contract with God or animals could supersede the social contract that institutes the state. The reason is because a contract is based on the capacity to respond freely, which Hobbes argued was proper to human beings. It is impossible to establish a contract with God because God does not respond. God communicates to humans only indirectly through scriptural revelation or "divine lieutenants"; he does not respond to us directly; "We know not whether our Covenants be accepted (Hobbes quoted in [1], p. 55)." In a parallel sense, it is impossible to make a contract with animals

1 At one point, Derrida states that the task of the seminar is to deconstruct, "The dominant, classical concept of nation-state sovereignty ([1], pp. 75-76)." In Derrida's view, this task arises from the fact that this deconstruction is already, "Happening today in the world ([1], p. 76)." It is happening through transformations of the global market, international law, phenomena of so-called national and international terrorism and wars declared and undeclared. In this sense, the seminar is in line with contemporary political thought that acknowledges that the concept of sovereignty associated with the nation-state is in crisis [3]. 
("bruit beasts"), because they do not respond either. Animals do not understand, "The translation of Right (Hobbes quoted in [1], p. 55)." In both cases, there cannot be a free exchange, a proposition and response, which a real contract demands. This is why Hobbes insisted that it was never justified to disobey political laws out of allegiance to a covenant with God or animals. Essentially, he argues that since a contract requires mutual acceptance to be valid, a valid contract cannot be made with non-human beings because only humans have the capacity to respond.

In defining the human in terms of the capacity to respond, Hobbes, Derrida suggests, participates in a tradition going "From Descartes to Lacan inclusive," which makes "The most powerful, impassive and dogmatic prejudice about the animal that [does] not consist in saying that it does not communicate, that it does not signify, and that it has no sign at its disposal, but that it does not respond ([1], p. 56). ${ }^{2}$, Derrida is not content to challenge this idea by claiming the possibility that animals do have the capacity to respond if we look more closely. More profoundly, he suggests that the criterion of 'response' itself is far less stable than the tradition assumes. ${ }^{3}$ The capacity to respond does not belong to human beings in 'all purity' and 'rigor' ([1], p. 57). For instance, Hobbes' formulation of the double exclusion (of beasts and God) that makes possible the social contract also associates beasts and God in a place of nonresponse. The beast and God overlap in their nonresponse. This is significant for Derrida because nonresponse can also be associated with "The most profound definition" of absolute sovereignty ([1], p. 57). The absolute sovereign is the one "Who does not have to be responsible for his acts ([1], p. 57)." S/he does not have to be held to account by a legislature or judiciary. Being unbound from a duty of reciprocity in this way is a form of nonresponse. From the perspective of this nonresponse, the sovereign looks like God, and God "Looks like the beast;" beast, human and God resemble each other from the place of nonresponse ([1], p. 57).

Derrida explores the idea of response further through the psychoanalysis of Jacques Lacan, who he shows also attributes the capacity for response to the human. Lacan characterizes animal behavior exclusively in terms of reaction, which he contrasts to the properly human ability to respond freely. A reaction is determined by a "code," which is a "fixed correlation of its signs with the reality they signify ([6], p. 297)." 'Reactions' are conceived as genetic and predetermined. In contrast, humans can respond freely in language, where meaning is not predetermined. Animals cannot be held responsible for their behavior because in the same way as humans because it has the "Fixity of a program ([1], p. 117)." Derrida notes the specificity of Lacan's formulation of this idea. The "Superiority of man over beast" is based on what is conceived as a "Defect, lack, or fault ([1], p. 125)," which is related to the "Anatomical incompleteness" of the human infant ([7], p. 78). That is, the altricial nature of the human species corresponds to an originary experience of lack that positions language as constitutive of

2 The question of what is proper to man is a recurring theme in the seminar (e.g., [1], pp. 15, 16, 56, 69). In this regard, Derrida also analyses the fact that what is characterised as bête, 'stupid,' in French, just like what is characterised as 'bestial' in Lacan, is in fact unique to humans and does not belong to the beast. Bêtise, as well as what is called bestial, are human characteristics. Derrida notes that elsewhere he has also explored how the distinction between reaction and response is problematic. See L'animal que donc je suis [4].

3 Derrida does question the category of the 'animal' elsewhere in the seminar. For instance, he refers to, "The scheme of my recurrent and deconstructive objections to this whole traditional discourse on 'the animal' (as though any such thing could exist in the general singular) ([1], p. 56)." Much of Derrida's work on the subject of the animal in The Beast and the Sovereign was published in a book titled The Animal That Therefore I Am [5]. 
the individual psyche and social order. ${ }^{4}$ The role of language is a consequence of this lack and a cover that enables the subject to take up a provisional position of enunciation in the symbolic order. Through language, humans have the capacity to go beyond reaction and engage in 'responsible response' ([1], p. 162). ${ }^{5}$

However, Derrida argues that just like with Hobbes there is an undecidability at play in Lacan's formulation. When Lacan characterizes lack as resulting from a 'generic' prematurity of birth in humans, the criterion of response as proper to humans loses its "decidability ([1], p. 179). ${ }^{6}$ " At issue is how the word 'generic' should be understood in this context. Is it referring to a trait of "The human genus as animal genus or a feature of the human insofar as it escapes from genus, generic, the genetic ([1], p. 134)?" Put another way: is this lack a trait of the human as an animal, or is it a specific difference on account of which the human exceeds the animal? Both interpretations are possible; however, Lacan seems to stake everything on the sovereignty of the subject in language. Derrida responds jokingly that in the case of the human/animal distinction, Lacan does not recognize "What is called the unconscious ([1], p. 183)." While he definitely affirms that the human is divisible and constituted by a multiplicity of drives and desires that are in tension or contradiction, the stability accorded to the response/nonresponse division is problematic. Derrida's point in highlighting this is not necessarily to deconstruct Lacan's theory, but similar to the reading of Hobbes, to the undecidability of the concept of response that underpins the animal/human division.

\section{A Problem of Firsts}

It is in the context of an undecidability of animal life and human life that the discussion of theories of biopolitics in The Beast and the Sovereign can be understood, specifically in regard to the work of Giorgio Agamben. Agamben is first mentioned in a discussion of the werewolf as a figure that blurs the difference between the animal and the human. Derrida suggests that his audience read a section of Agamben's book Homo Sacer called "The Ban and the Wolf." The section discusses werewolves as well as a famous phrase used by Hobbes in Leviathan to describe the state of nature: homo hominis lupus (man is a wolf to man) ([2], pp. 104-109). Agamben insists that the meaning behind Hobbes use of the phrase can only be understood in light of Rodolphe Jhering's work on the figure of the werewolf in ancient Germanic law. Jhering was a nineteenth-century legal scholar who Hobbes likely would have read. He analyzed the werewolf as a form of life paradoxically both inside and outside the law. Ancient Germanic law was founded on the concept of peace (Friede). The connected exclusion of a wrongdoer from the community determined them as friedlos, which means 'without peace' (Jhering cited in [2], p. 104). This status did not mean one was completely disconnected from the law, as

4 'Altricial' is a term from biology that refers to organisms which are incapable of moving around on their own soon after birth and need to be cared for a long time by adults. In this case, we are referring to the prematurity of birth of the human infant.

5 Derrida shows a similar tendency to divide the human and the animal in several texts by Lacan. For example, in a text that argues that criminality (specifically cruelty) is a unique human capacity that animals do not possess, Lacan again invokes the idea of reaction/responsibility to differentiate the human from the animal [8].

6 Lacan refers to lack in terms of the "Genetic prematurity of birth" in the essay "Subversion of the Subject and Dialectic Desire in the Freudian Unconscious" ([9], p. 689). 
animals were, but rather that the conditions for peace (law) were withdrawn. A Friedlos could be killed without legal sanction and it was forbidden to provide such an individual shelter ([2], p. 105). In this sense, the law still applied to the Friedlos by maintaining a relation of not applying. It was a form of life that was included in the law by being excluded from it. Jhering argued that the werewolf should be seen as a form of friedlos. Those with the status of friedlos were positioned between the human and the animal from the perspective of law, like the werewolf belonging to both and properly to neither.

Agamben argues that the werewolf is akin to another figure in medieval law, that of the bandit. The bandit was literally 'banned' by the law. It could be killed without the death being a homicide and it was forbidden to shelter a bandit. In this sense, the law applied to the bandit in the maintenance of the relation of ban. Agamben notes how bandits were often associated with wolves. For instance, the laws of Edward the Confessor (1030-1035) contained a juridical statute called caput lupinum, which describes the bandit as bearing a 'wolf's head' (wulfesheud) ([2], p. 105). Other Germanic and Anglo-Saxon sources marked the bandit's liminal status by defining it as a wolfman (wargus) ([2], p. 104). Thus, Agamben argues that the figure of the werewolf, "In its origin," is one who has been banned from the city ([2], p. 105). The significance of this is the idea that evident in the relation of ban is also a form of life constituted by the status of being excluded from the law.

Agamben connects this idea of a form of life, exemplified by the figure of the werewolf, to Hobbes' use of the phrase homo hominis lupus to describe the state of nature. He argues that the meaning of Hobbes' characterization can only be understood in light of Jhering and the idea of the werewolf as a threshold between human and animal that is also a threshold of law. When Hobbes founds sovereignty with reference to a state in which 'man is wolf to man,' "In the word 'wolf' we ought to hear the echo of the wargus and the caput lupinum of the laws of Edward the Confessor ([2], p. 106)." Based on this, Agamben suggests that the state of nature should not be understood as referring to a condition prior to the foundation of a legal order, but, rather, to a threshold internal to law that appears when the law is considered "Tanquam dissolute, 'as if it were dissolved' ([2], p. 105)." In other words, the state of nature is not a condition prior to law. It is a principle internal to law where the law withdraws itself to create an exception.

Derrida's response is to point out, first of all, that there are "Wolves being forgotten" by Agamben when he declares Jhering as the only reference through which Hobbes' use of the phrase homo hominis lupus can be understood ([1], p. 92). For instance, the phrase is also found in the writing of an ancient Roman playwright named Plautus. The full line from Plautus is "Lupus est homo homini, non homo, quom quails sit non novit," which is translated as "Wolf is man for man, and not a man, when one does not know which he is" ([1], p. 61). In light of Plautus, Derrida suggests that homo homini lupus in Hobbes could stand for "What is most unknown in man ([1], p. 61)." Hobbes' use of the phrase could imply that whenever someone does not know if another is a human or wolf, the other becomes a wolf. This does not necessarily signal anything about an internal threshold of law. The state of nature could simply refer to a condition where the human is a wolf inasmuch as one does not know them. In this sense, Derrida complicates Agamben's idea of internal threshold of law by arguing (via

Another example is Jean-Jacques Rousseau's references to the werewolf. For instance, in the Confessions, Rousseau describes himself as a werewolf because of an, "Immoderate, compulsive, raging taste for reading, for book culture, and for buying books ([1], p. 63)." 
Plautus) that the state of nature represents what is most unknown in another. The point, however, is once again not to provide an alternative interpretation of the state of nature, but to point out that Agamben's 'forgetting' of Plautus is representative of an "Irrepressible gesture" in his theory of declaring the origin or definitive meaning of an idea or concept ([1], p. 92).

There are several other examples of this tendency in Homo Sacer besides that of Hobbes and Jhering. For instance, Agamben credits Hegel with being "The first to truly understand the presuppositional structure thanks to which language is outside itself (Agamben quoted in [1], p. 93)." Derrida's rejoinder is to say that not only was Hegel not the first to theorize language as outside itself, but it would be hard to find anyone in the history of philosophy of language who did not say this idea or at least imply it. Another example is Agamben's discussion of an ancient Roman ritual where, upon the death of an emperor, a wax effigy ('wax imago') was created and treated as the emperor's living person for several days by senators and matrons, as well as physicians who pretended to feel the pulse and give it treatment until it 'died' ([2], p. 93). Agamben admits that the ritual was discussed by Ernst Kantorowicz in The King's Two Bodies, but insists he failed to recognize its 'true' meaning. He declares, rather, that "The specific aporia contained in the "funeral by image"" was first understood by an obscure scholar of classical antiquity named Elias Bickermann ([2], p. 94).

For Derrida, this argumentative style, which consists in "Recognizing priorities... first times, inaugural initiatives, instituting events" is problematic ([1], p. 93). First of all, it excludes alternative interpretations and strands of thought, as exemplified in the discussion of Plautus. Second, it turns Agamben himself into a "first': "The first to say who will have been first," and the first to "Really understand the first ones," and to locate them properly in the tradition of theoretical thought ([1], p. 92). This form of self-positing is a form of sovereignty according to Derrida:

He who posits himself as sovereign or intends to take power as sovereign always says or implies; even if I

am not the first to do or say so, I am the first and only one to know and recognize who will have been the first ([1], p. 92).

The full implications of this criticism become clear later in the seminar, when Derrida draws them out with reference to specific aspects of Agamben's theory of biopolitical sovereignty. Specifically, he takes the criticism above and uses it to critique Agamben more generally, arguing that his desire to set internal thresholds to law is mirrored by an attempt to impart thresholds and origins to philosophy and history, and, in the process, to establish himself as a 'first' to see or do these things as well (which is a form of sovereignty, according to Derrida). The point is that there might be a contradiction in declaring the origin of certain ideas and concepts, while at the same time critiquing the concept of sovereignty. Before turning to this discussion directly, however, the next few pages will outline some salient aspects of Agamben's theory that provide context to evaluate Derrida's criticism.

\section{Agamben and the 'Origin' of Politics}

In Homo Sacer, Agamben attempts to define sovereignty as a relation between law and life that has always organized the politics of the West. To develop this claim, he draws on various sources in the history of legal and political thought. One of the most important is German jurist Carl Schmitt's definition of sovereignty as the decision to declare a 'state of exception'. A state of exception involves 
the suspension of the rule of law, typically in the context of an emergency. In this situation, the force of law is not bound by the rule of law. The law displays the character of "Being in force without significance ([2], p. 37)." In a state of exception any sovereign action, legally valid or not, can potentially have legal force. ${ }^{8}$ This leaves individuals vulnerable to unsanctionable legal violence. One of Agamben's key arguments is that while this situation might have been originally envisioned by Schmitt as an exception to the norm, in the contemporary moment a permanent state of exception is increasingly normal. There is a trend around the globe to generalize the state of exception and displace the rule of law, even in democratic states.

An important part of Agamben's theory is defining the form of life that corresponds to the state of exception, which he terms 'bare life'. He argues that if sovereignty is constituted by the decision on the state of exception, bare life is the form of being that is 'captured' in the state of exception. Similar to the werewolf and the bandit, it is constituted by being inclusively excluded by the law. He generates the concept by turning to ancient sources, for instance, an obscure figure in ancient Roman law called the homo sacer, or 'sacred man'. In Roman law, the homo sacer had a peculiar legal status. It was a person who was excluded from human law, and could therefore be killed without legal sanction. Simultaneously, the homo sacer was excluded from religious law, so its death could not count as a sacrifice to the Gods ([2], pp. 11-25). The homo sacer was therefore a form of life fully determined by the legal status of inclusive exclusion, that is, as life from which law has withdrawn. In this way, Agamben draws a filial line from bare life to the bandit, the werewolf, and the homo sacer. He also argues that the relation between bare life and sovereignty is the originary political relation; it is the essence of politics.

To further bolster this claim, Agamben turns to other ancient sources, specifically 'the Greeks', who apparently had two terms to express what we mean today by the word 'life' ([2], p. 1). ${ }^{9}$ Zoe meant the

8 For example, in Canada, the War Measures Act allowed for an extension of government power beyond constitutional limits in times of war or insurrection, real or apprehended. This Act was used during the two world wars and the October Crisis in 1970. It was superseded by the Emergencies Act in 1988.

9 Laurent Dubreuil makes a good point about Agamben's interpretation of bios and zoe that Derrida does not address. He argues that Agamben uses Aristotle as a stand-in for the 'Greeks' in general, but that there are different ways of using the terms evident in other Greek texts. He writes, "Aristotle has perhaps the tendency to place bios more on the side of particular life (vegetable or aquatic existence in the city) and zoe on the general. One would have the play between a marked substantive and an unmarked one, linguistically speaking. But in no case can bios be reserved to either humans or political practice (...) Take, for example, the phrase 'living [zēn] the life [bion] of a plant.' One reads as well that 'the differences among animals [zōon] are relative to their lives [bíous], their characteristics, and their organs"” ([10], p. 85). At the same time, Agamben uses Aristotle to stand in for 'The Greeks' in general ([2], p. 1). However, Dubreuil states the obvious: Aristotle, "Is not the entire Greek corpus ([10], p. 85)." Bios and zoe have an opposed meaning if one looks at the writing of other Greeks. For example, "In the second chorus of Heracles, Euripides invents a moral postmortem in which the good people, having arrived at the end of their years, are offered a second chance, while the bad are to be punished by a death without return. (...) 'villainy would have only one life [bioton] in life [zoas].' (...) He literally says, 'one life's life,' or 'one life of life.' (...) Bios is a portion, or the subcase, of zoe, somewhat as with Aristotle. Let us hasten to cite another phrase, one that indicates the exact and dynamic inverse. Here is a bit from Plato, who, in the Timaeus, imagines a psychic migration proximate to Euripides's chorus. He mentions a soul which 'spent a lame life throughout life' [44c] — final exchange of terms, in which this time bios denotes life in general, and zōē, a singular lifetime ([10], pp. 85-86).” 
simple fact of living common to all beings (animals, humans, gods), and bios meant a qualified form of life proper to an individual or group, such as the contemplative life of the philosopher or political life in the polis. ${ }^{10}$ Agamben claims that this distinction between the fact of living and a qualified form of life is the foundation of Aristotle's concept of the political.

In the Politics, Aristotle argues that concern for basic survival is what first draws humans into proximity and leads to group living; however, the purpose of human life is not simply living, but living a happy life [11]. For Aristotle, happiness (Eudemonia) is the objective purpose of human life. ${ }^{11}$ True happiness comes about through acting in virtuous ways. Virtuous conduct is that which is done in accordance with logos, which means both 'speech' and 'reason.' ${ }^{12}$ According to Aristotle, human beings alone have the ability to engage in reasonable dialogue. We use our reason together to discover what is right and wrong, what is good and bad, and what is just and unjust. A necessary condition for happiness, therefore, is a system of laws that allows for the development of individual virtuous character. That is, political communities are a condition of possibility for happiness, which is the highest good. In this sense, a city, "While coming into being for the sake of living [zoe], exists for the sake of living well [bios] ([11], p. 1252b27, 1281a1)." Agamben argues that with this formulation Aristotle excluded natural life, the basic fact of living (zoe), from the polis "In the strict sense ([2], p. 2)." The form of this exclusion and the form of life it corresponds to, of course, remain included as a limit threshold. Based on this Agamben argues that the relationship between sovereignty and bare life is an 'immemorial' political relation ([2], p. 6).

To explore this relationship in the contemporary context, Agamben connects the concept of bare life to Michel Foucault's discussion of biopower and biopolitics. In The History of Sexuality [12], Foucault describes how historically sovereignty manifested in localized displays of spectacular violence, such as public executions. These manifestations started to decline in frequency in the modern era at the same time as the value of life and the health of the population became a concern of the state [12]. At the same time, a new 'biopower' emerges that involves caring for the life of the population. Biopower is concerned with indicators of population health, such as birth rates, illness rates, life

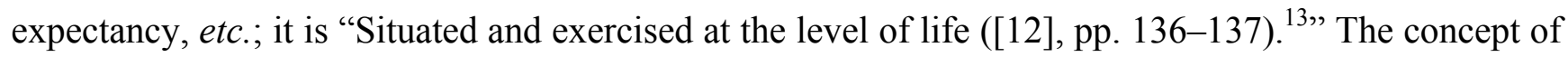
'biopolitics' corresponds to a situation in which the life of the population becomes what is at stake in

10 'The Greeks had no single term to express what we mean by the word 'life.' They used two terms (...): zoe, which expressed the simple fact of living common to all living beings (animals, men, or gods), and bios, which indicated the form or way of living proper to an individual or a group ([2], p. 1). "Throughout Homo Sacer, Agamben expresses this opposition in various ways, for example, "Life in general and the qualified way of life proper to men ([2], p. 66)," or "private life and political existence" ([2], p. 187).

11 Aristotle discusses the notion of the good life In the Nicomachean Ethics, where he posits that the gods were the happiest beings because they enjoyed the, "Single and simple pleasure," of rational contemplation ([13], p. 1154b26). The happy life for humans consisted in imitating the thinking of a god ([13], pp. 1778x7-8, 1144b3-17).

12 Derrida spends a significant amount of time in the twelfth session of the seminar addressing the meaning of Logos in Aristotle and Heidegger.

13 In the seminar Security, Population and Territory Foucault defines biopower as (...) the set of mechanisms through which the basic biological features of the human species became the object of a political strategy, of a general strategy of power, or, in other words, how, starting from the 18th century, modern Western societies took on board the fundamental biological fact that human beings are a species ([14], p. 1). 
normal political decisions. Agamben argues from this that the distinguishing feature of politics in the modern era is how the relation between sovereignty and bare life does not appear at the limit of the legal order as it did in ancient and medieval times, but is immediately political in the state of exception. In other words, if the homo sacer was a liminal figure in the Roman social order, today in the biopolitical all individual lives are potentially homo sacrii ([2], p. 9). Every life is potentially bare life vis-à-vis the life of the population. He claims to be 'correcting' and 'completing' Foucault's analysis by arguing that sovereignty is not opposed to biopower, but rather has always been constituted in relation to bare life.

\section{A Problem of Firsts Redux}

Derrida's issue with this conception of sovereignty is multi-layered. As mentioned above, he begins by pointing out how it involves the naming of firsts: Agamben "Wants to be the first to announce an unprecedented new thing (...) and also to be the first to recall that in fact it's always been like that, from time immemorial ([1], p. 332)." Indeed, Agamben claims both that the "Production of a biopolitical body [is] the originary activity of sovereign power," and that the politicization of bare life in the state of exception is the "Decisive event of modernity ([2], pp. 4, 6)." That is, he claims to be uncovering the essence of sovereignty in the state of exception, while at the same time identifying the entry of bare life into the polis as distinguishing of modernity. Derrida insists that the confusions and contradictions inherent in this formulation are obscured by the naming of firsts. To illustrate, let us turn more closely to the attribution of the zoe/bios distinction to Aristotle and scrutinize whether it can indeed be found in his ancient text.

For Agamben's theory to hold, the difference between zoe and bios must really be present in Aristotle. However, Derrida points out several instances where Aristotle seems to use the term zoe in a way that contradicts the interpretation that Agamben puts forward. One significant exception would seem to be the famous definition of the human being as politikon zoon ('political animal'). With the term politikon zoon, Aristotle seems to be describing a zoe that is political. In fact, Derrida points out that zoe, or zen ('to live'), is used repeatedly by Aristotle in the Politics to describe the human as a political animal, and each time he "Never fails to specify" that the human zoon is political "By nature" (physei) (Aristotle quoted in [1], p. 315). This specification implies that the descriptor 'political' refers to how humans live naturally, and is thus a qualification of their animal life. Being political is a natural attribute of human life and their specific difference from other animals. The definition of the human as politikon zoon, therefore, would seem to be a glaring exception to the zoe/bios distinction. Agamben addresses the issue by claiming that there is no contradiction if one interprets the meaning of the qualifier politikon properly. Here is the passage:

It is true that in a famous passage of the same work [the Politics], Aristotle defines man as a politikon zoon (Politics 1253a, 4). But here (aside from the fact that in attic Greek the verb bio nai is practically never used in the present tense), "political" is not an attribute of the living being as such, but rather as a specific difference that determines the genus zoon ([2], p. 2).

Agamben is arguing that there is a difference between an attribute of a living being and a specific difference that defines the living being. Yet, Derrida's position is that this difference is neither certain 
nor clear. The phrase politikon zoon implies both: "The specific difference or the attribute of man's living, in his life as a living being, in his bare life, if you will, is to be political ([1], p. 330)." There is no clear difference between the two notions. They seem to be "Perfectly reciprocal" and 'complementary' ideas ([1], p. 330). Thus, Derrida insists that Aristotle did not oppose zoe and bios as Agamben suggests. The concept of politikon zoon implies there was never any such distinction in his concept of the political; for Aristotle, "Man is that living being who is taken by politics: he is a politically living being, and essentially so ([1], p. 348)." Thus, Derrida claims that it is 'obvious' that Aristotle is already "Thinking of biopolitics ([1], p. 349)." However, the division in life that apparently structures sovereignty is not based in his ancient text in the way that Agamben implies. The distinction is of Agamben's own making much more than the argumentative gesture he deploys would suggest.

It is evident that Derrida agrees with Agamben that biopower is an important concept in the contemporary moment. He notes the "Incredible novelties in bio-power" that must be addressed, but there is an issue concerning the "conceptual strategies relied on" to characterize these novelties ([1], pp. 330, 326). Derrida's reading of Aristotle demonstrates the zoe/bios distinction, which is "The frontier along which Agamben constructs his whole discourse," does not go deep enough to function as an originary political relation ([1], p. 321). Moreover, the insistence on seeing historical and philosophical origins, exemplified by the reading of the bios/zoe division in Aristotle is, in effect, producing the very sovereign form of exclusion that Agamben criticizes in his work. This is not to suggest that Derrida's position is that ancient texts are not relevant to contemporary politics. On the contrary, they are 'indispensable' for understanding the "Bio-powers or zoo-powers of what we call the modernity of 'our time' ([1], p. 333)." The issue however is how to conceive of the relationship between these texts and 'our time,' how to think history neither in terms of 'diachronic succession' nor 'synchronic simultaneity' ([1], p. 333). Agamben's approach involves thinking history in terms of “A decisive and founding event ([1], p. 333).” Derrida's criticism intends to compel a reconsideration of this way of "Thinking history, of doing history, of articulating a logic and a rhetoric onto a thinking of history ([1], p. 332).”

The difference in conceiving history corresponds to a difference in the two thinkers' positions on the future of sovereignty. On the one hand, Derrida rejects conceptualizing sovereignty in terms of an essential relation. The readings in The Beast and the Sovereign suggest instead that sovereignty has "More than one ground (...) more than one solid and single threshold ([1], p. 334)." This is not to suggest Derrida leaves us with an abyssal void or groundless depth underlying the concept; rather, it suggests that there are multiple forms of partition, division, and condition that broach a sovereignty that is imagined to be indivisible. If this is correct then it is not possible to oppose sovereignty because sovereignty is not one thing. ${ }^{14}$ For instance, to unconditionally oppose sovereignty would mean opposing classical principles of freedom and self-determination. There is no way to conceptualize freedom without a certain sovereignty. Thus, it is impossible to reject sovereignty without also threatening the value of liberty. The issue is therefore not a choice between sovereignty

14 For instance, to unconditionally oppose sovereignty would mean opposing classical principles of freedom and autonomy. Derrida argues that there is no way to conceptualise freedom without a certain sovereignty. Therefore, it is impossible to reject sovereignty without also threatening the value of liberty. 
and non-sovereignty but among ways of sharing, transferring, translating, and dividing sovereignty. ${ }^{15}$ In contrast, Agamben's formulation conceives sovereignty in terms of an essential relation to bare life. The idea of an essential political relation implies that it might be possible to overcome sovereign politics, if only the relation were discarded. ${ }^{16}$ Sovereignty could be abandoned and a "coming community' ushered in, in which there would be no exception of the fact of living from the form of life $[20] .{ }^{17}$

\section{Conclusions}

Derrida is no doubt correct that Agamben forces the origins he claims to be naming. However, this does not necessaruly mean that defining sovereignty essentially is undesirable or morally problematic. Taking a position on the difference in Derrida and Agamben's view of sovereignty depends on factors beyond the texts in question. It is a decision that is properly taken in the context of situations where such decisions are demanded. In a sense, Agamben and Derrida are both correct. Derrida brings the fundamental problem of the metaphysics of sovereignty to light, even if he remains focused on the interminable undecidability it implies. Agamben in contrast does not dwell on undecidables infinitely in excess of signification; he rather produces a compelling account with significance in the present moment, admittedly with all the risks this entails according to Derrida.

\section{References}

1. Derrida, J. The Beast and the Sovereign; Lisse, M., Mallet, M.-L., Michaud, G., Eds.; Bennington, G., Trans.; University of Chicago: Chicago, IL, USA, 2009; Volume 1.

2. Agamben, G. Homo Sacer: Sovereign Power and Bare Life; University of California: Stanford, CA, USA, 1998.

3. Barbour, C.; Pavlich, G. After Sovereignty: On the Question of Political Beginnings; Routledge: New York, NY, USA, 2010.

4. Derrida, J. L'animal que donc je suis; Galilée: Paris, France, 2006.

5. Derrida, J. The Animal That Therefore I Am; Fordham University: New York, NY, USA, 2008.

6. Lacan, J. The Function and Field of Speech and Language in Psychoanalysis. In Ecrits: The First Complete English Edition; Fink, B., Trans.; Norton: New York, NY, USA, 2006; pp. 197-268.

7. Lacan, J. The Mirror Stage as Formative of the I Function, as Revealed in Psychoanalytic Experience. In Ecrits: The First Complete Edition in English; Fink, B., Trans.; Norton: New York, NY, USA, 2006; pp. 75-81.

8. Lacan, J. A Theoretical Introduction to the Functions of Psychoanalysis in Criminology. In Ecrits: The First Complete Edition in English; Fink, B., Trans.; Norton: New York, NY, USA, 2006; pp. 102-122.

15 Derrida's elaborated analysis of sovereignty can be found in the book Rogues [15]. There are sections of the book very similar to sections from The Beast and the Sovereign.

16 For some critical response to Agamben's 'utopian' meditations, see [16] and [17]. For a discussion of how Agamben is able to hold in tension what is essentially an indictment of the entire tradition of western politics since Aristotle, while remaining hopeful that there is nonetheless another form of law, see [18].

17 For more of Agamben's work on the idea of a 'coming politics', see [19] and [20]. 
9. Lacan, J. Subversion of the Subject and Dialectic of Desire in the Freudian Unconscious. In Ecrits: First Complete Edition in English; Fink, B., Trans.; Norton: New York, NY, USA, 2006; pp. 671-702.

10. Dubreuil, L.; Eagle, C.C. Leaving politics: Bios, Zoe, life. Diacritics 2006, 36, 83-98.

11. Aristotle. The Politics; Lord, C., Trans.; University of Chicago: Chicago, IL, USA, 1984.

12. Foucault, M. History of Sexuality Volume One: An Introduction; Vintage: New York, NY, USA, 1990.

13. Aristotle. The Nicomachean Ethics; Irwin, T., Trans.; Hackett: Indianapolis, IN, USA, 1999.

14. Foucault, M. Security, Territory, Population: Lectures at the Collège de France 1977-1978; Senellart, M., Ed.; Burchell, G., Trans.; Palgrave Macmillan: Basingstoke, UK, 2007.

15. Derrida, J. Rogues: Two Essays on Reason; Brault, P.-A., Naas, M., Trans.; Stanford University: Stanford, CA, USA, 2005

16. Passavant, P.A. The contradictory state of Giorgio Agamben. Polit. Theor. 2007, 35, 147-174.

17. Negri, A. The Ripe Fruit of Redemption. Available online: http://www.generation-online.org/t/ negriagamben.htm (accessed on 30 June 2012).

18. Agamben, G. Means without Ends: Notes on Politics; Binette, V., Casarino, C., Trans.; University of Minnesota: Minneapolis, MN, USA, 2000.

19. Swiffen, A.; Kellogg, C. Pleasure and political subjectivity: Fetishism from Freud to Agamben. Theory and Event. Project MUSE. Available online: http://muse.jhu.edu/ (accessed on 30 June 2012).

20. Agamben, G. The Coming Community; Hardt, M., Trans.; University of Minnesota: Minneapolis, MN, USA, 1993.

(C) 2012 by the author; licensee MDPI, Basel, Switzerland. This article is an open access article distributed under the terms and conditions of the Creative Commons Attribution license (http://creativecommons.org/licenses/by/3.0/). 